\title{
Pemanfaatan Tumbuhan Berkhasiat Obat Berbasis Pengetahuan Masyarakat Lokal Kampung Nanggouw Distrik Sausapor Kabupaten Tambrauw
}

\author{
Muzna Ardin Abdul Gafur ${ }^{*}$ \\ Universitas Muhammadiyah Sorong, Sorong, Indonesia \\ *E-mail: muznagafur@gmail.com
}

\begin{abstract}
ABSTRAK
Kampung Nanggouw Distrik Sausapor Kabupaten Tambrauw merupakan perkampungan penduduk asli suku Abun, terletak di wilayah Pesisir Dsitrik Sausapor Kabupaten Tambrauw. Kampung ini berjarak $108 \mathrm{~km}$ dari Kota Sorong, dapat ditempuh dengan perjalanan darat selama lebih kurang 5 jam menggunakan kenderaan roda empat. Permasalahan utama di kampung ini adalah rendahnya tingkat kesehatan masyarakat. Penyakit yang umumnya menyerang adalah malaria, infeksi paru-paru dan penyakit kulit. Fasilitas kesehatan dan pendukungnya masih sangat kurang, di kampung ini tidak terdapat puskesmas. Untuk berobat, masyarakat harus ke Ibukota Distrik atau ke Ibukota kabupaten. Salah satu alternatif penyelesaian masalah kesehatan di Kampung Nanggouw adalah dengan cara membekali masyarakat agar dapat mengatasi permasalahan kesehatan secara mandiri. Kampung dengan kekayaan sumber daya alam yang besar ini memiliki potensi tumbuhan obat yang cukup banyak, akan tetapi informasi dan pengetahuan masyarakat terhadap mafaat tumbuhan obat itu masih sangat kurang. Oleh sebab itu dianggap penting untuk memberikan informasi, pengetahuan, dan pengalaman tentang jenis-jenis tumbuhan berkhasiat obat, cara pengolahan dan penyiapannya dalam bentuk siap pakai. Kegiatan pengabdian ini dilakukan dalam bentuk sosialisai dan penyuluhan kepada masyarakat terutama ibu-ibu, pemuda dan remaja.
\end{abstract}

Kata kunci: Kampung nanggouw; Masyarakat lokal; tumbuhan berkhasiat obat

\section{Utilization of Knowledge-Based Medicinal Plants from the Local Community in Nanggouw Village, Sausapor District, Tambrauw Regency}

\begin{abstract}
Nanggouw Village, Sausapor District, Tambrauw Regency is a village for the indigenous people of the Abun tribe, located in the coastal area of Sausapor District, Tambrauw Regency. This village is 108 $\mathrm{km}$ from Sorong City, which can be reached by road trip for approximately 5 hours using a fourwheeled vehicle. The main problem in this village is the low level of public health. The diseases that commonly attack are malaria, lung infections and skin diseases. Health facilities and supporting facilities are still lacking, in this village there is no health center. For treatment, people must go to the district capital or the district capital. One of the alternative solutions to health problems in Nanggouw Village is to equip the community to be able to handle health problems independently. This village with a large wealth of natural resources has the potential for quite a lot of medicinal plants, but the information and knowledge of the people about the benefits of medicinal plants is still lacking. Therefore, it is considered important to provide information, knowledge and experience about medicinal plant types, how to process and prepare them in a ready-to-use form. This service activity is carried out in the form of socialization and outreach to the community, especially mothers, youth and adolescents.
\end{abstract}

Keywords: Local community; medicinal plants; nanggouw village 


\section{PENDAHULUAN}

Hutan Papua memiliki kekayaan sumber daya alam hayati, diantaranya adalah tumbuhan berkhasiat obat tetapi belum banyak masyarakat yang memiliki pengetahuan tentang hal ini. Seiring dengan tingginya permasalahan kesehatan dalam masyarakat, kekayaan sumber daya alam hayati ini menjadi salah satu alternatif yang dapat di manfaatkan, terutama dalam pencegahan penyakit tertentu. Pengetahuan terntang jenis tumbuhan berkhasiat obat dan cara pemanfaatannya menjadi salah satu yang di anggap penting.

Kampung Nanggouw Distrik Sausapor Kabupaten Tambraw merupakan perkampungan yang mayoritas penduduknya masyarakat adat suku Abun. Kampung ini terletak di daerah pesisir, di sebelah utara berbatasan dengan Kampung Mega, sebelah selatan berbatasan dengan Kampung Jokte, sebelah Timur berbatasan dengan hutan alam, dan sebelah barat berhadapan dengan laut.

Permasalahan utama yang ada di kampung ini adalah minimnya fasilitas kesehatan dan tenaga medis. Di kampung ini tidak terdapat puskesmas. Untuk berobat, masyarakat kampung Nanggouw harus ke puskesmas pembantu di Pusat Distrik Sausapor, atau berobat ke RSUD Kota Sorong. Keterbatasan fasilitas kesehatan menyebabkan masyarakat tidak dapat mengatasi permasalah kesehatan mereka secara cepat.

Kampung ini terletak di daerah pesisir, dan dekat dengan hutan alam/ hutan adat yang memiliki beragam sumber daya botani yang masih utuh. Kabupaten Tambrauw memiliki kekayaan sumber daya alam yang cukup besar, meliputi keragaman Flora, Fauna, dan sumber daya mineral. Kabupaten ini mengikrarkan dirinya sebagai Kabupaten yang sadar akan kelestarian alam, dimana 80\% wilayah administrasinya merupakan kawasan konservasi. Mbur, Nden, Mikindewa Membau (tanah, hutan, dan laut di lindungi untuk kehidupan) ialah semboyan popular untuk menggugah kesadaran masyarakat akan pentingnya alam lestari.

Masyarakat lokal terbiasa memanfaatkan tumbuhan sebagai obat dan pencegahan beberapa jenis penyakit tertentu. Pengetahuan akan hal itu di dapatkan secara turun temurun. Akan tetapi, pengetahuan mereka terhadap jenis-jenis tumbuhan berkhasiat obat masih terbatas pada beberapa jenis tumbuhan saja. Beberapa jenis tumbuhan bahkan memiliki potensi minyak atsiri yang berkhasiat mengobati jenis penyakit tertentu. Secara umum, Papua memiliki ribuan species tumbuhan yang potensial sebagai penghasil minyak atsiri. Agusta (2000) mengemukakan tentang family tumbuhan Lauraceae, Myrtaceae, Rutacea, Myristicaceae, Astereaceae, Apocynaceae, Umbeliferae, Pinaceae dan Rosaceae merupakan tumbuhan penghasil minyak atsiri.

Sebenarnya masih lebih banyak lagi tumbuhan yang memiliki potensi untuk digunakan sebagai obat, akan tetapi masyarakat belum mengetahuinya secara luas. Disamping itu, pengetahuan masyarakat sangat terbatas dalam hal mengolah Tumbuhan obat tersebut untuk menjadi simplicia atau tersedia sebagai obat. Menurut Hikmat dkk (2011), rendahnya pengetahuan masyarakat dalam pemanfaatan tanaman obat dipicu oleh kurangnya informasi mengenai jenis tanaman yang bisa dimanfaatkan sebagai tanaman obat dalam meningkatkan kesehatan keluarga. Hal ini diperkuat oleh Savitri (2016) yang menyatakan bahwa pemanfaatan tanaman yang berkhasiat obat apabila dipahami dengan baik tentu akan menjadi pilihan keluarga dalam memilih obat alami yang aman digunakan.

Permasalahan utama masyarakat di kampung Nanggouw adalah: 1). Fasilitas dan pelayanan kesehatan yang masih minim. Kampung Jokte tidak memiliki puskesmas pembantu atau fasilitas kesehatan lainnya. Untuk berobat, masyarakat harus ke Puskesmas di Ibukota Distrik Sausapor, atau ke RSUD Kota Sorong. 2). Poternsi sumber daya Alam (botani) yang melimpah tapi pengetahuan tentang pemanfaatan tumbuhan berkhasiat obat belum diketahui secara luas. Kampung Nanggouw memiliki hutan alam tropis yang masih terpelihara, dengan beragam jenis tumbuhan yang dapat dimanfaatkan sebagai obat. Namun pengetahuan masyarakat tentang jenis tumbuhan dan cara pengolahan menjadi obat, masih sangat terbatas. 3). Kemampuan mengakses informasi teknologi tentang pemanfaatan tumbuhan berkhasiat obat masih sangat kurang. Di era informasi teknologi seperti sekarang ini, sebagian besar masyarakat kampung Nanggouw tidak mengetahui cara mendapatkan informasi secara mudah terutama yang 
berkaitan dengan tumbuhan obat dan pengolahannya. Hal ini antara lain juga di sebabkan oleh karena daerah ini masuk dalam kategori daerah terpencil, tidak memiliki jaringan intenet atau jaringan telekomunikasi lainnya.

Berdasarkan permasalahan yang telah diuraikan diatas, maka sangat penting melakukan sosialisasi dan pelatihan kepada masyarakat tentang pemanfaatan tumbuhan berkhasiat obat, sekaligus metode pengolahannya.

\section{METODE}

Pelaksanaan kegiatan dilaksanakan di Kampung Nanggouw, Distik Sausapor, Kabupaten Tambrauw. Sosialisasi tentang Jenis tumbuhan obat dan cara pemanfaatannya di laksanakan dalam bentuk penyuluhan dan praktek langsung.

Penyuluhan diawali dengan memperkenalkan beberapa jenis tumbuhan yang berkhasiat obat, terutama tumbuhan yang sudah di kenal dan berada di alam sekitar kampung Nanggouw. Jenis-jenis tumbuhan berkhasiat obat ini di kelompokkan penggunaannya berdasarkan bagian tumbuhan, meliputi Daun, akar, batang, buah dan biji.

Beberapa tumbuhan endemik hutan kampung Nanggouw di jelaskan kembali cara pembuatan simplisia dan pengolahannya sesuai standar kesehatan. Misalnya pengolahan daun tumbuhan Gedi (Abelmoschus manihot) untuk melancarkan persalinan, daun Kayu Papuana untuk mengurangi pegel-pegel, daun Gatal (Laportea ducumana) untuk mengobati kecapeaan .

Beberapa jenis tanaman yang dikenal berkhasiat obat dan tidak terdapat di kampung Nanggouw, diperkenalkan melalui gambar dan tayangan dalam rekaman Handphone, disosialisasikan pula teknik budidaya tanaman berkhasiat obat tersebut, seperti: tanaman seledri, temulawak, kunyit, jahe, kumis kucing, dan lain sebagainya.

\section{HASIL DAN PEMBAHASAN}

Berdasarkan hasil kegiatan penyuluhan yang telah dilakukan, masyarakat sangat memberikan respon positif dalam mengikuti kegiatan. Secara umum, kegiatan berjalan lancar dan masyarakat yang hadir menyimak materi yang disampaiakn terutama menyangkut jenisjenis tumbuhan yang biasa di manfaatkan untuk mencegah beberapa jenis peyakit tertentu di kampung Nanggouw, seperti penyakit kulit, batuk, dan influenza. Kegiatan penyuluhan ini tidak hanya kebanyakan dihadiri oleh ibu-ibu, tetapi juga dihadiri oleh Bapak-bapak bahkan anak kecil. Selain itu juga sempat dihadiri oleh Kepala Kampung Nanggouw dan pejabat pemerintah desa lainnya.

Pada saat sosialisasi dilakukan pula pengenalan jenis tumbuhan berkhasiat obat di alam hutan sekitar kampung Nanggouw, sebagian di antaranya merupakan jenis tumbuhan yang sudah dimanfaatkan sebagai obat secara turun temurun, misalnya daun Gedi yang di gunakan oleh masyarakat untuk di konsumsi oleh Ibu hamil, berkhasiat melancarkan persalinan. Pengolahannya dengan cara merebus daun gedi dan airnya diminum oleh ibu hami lmenjelang waktu persalinan, dan setelah persalinan. Daun gatal digunakan untuk menggosok seluruh badan apabila kecapeaan setelah berkebun atau setelah melakukan perjalanan jauh. Menurut Rahmawati dkk (2019), masyarakat yang telah diberikan sosialisasi tentang tanaman obat keluarga mampu lebih memaksimalkan berbagai tanaman sebagai pengobatan dan pencegahan berbagai penyakit secara alami. Sari, dkk (2019) menyatakan bahwa upaya kesehatan bersumberdaya manusia adalah salahsatu wujud nyata peran serta masyarakat dalam pembangunan Kesehatan sebagai pemicu kegiatan pemberdayaan masyarakat. 


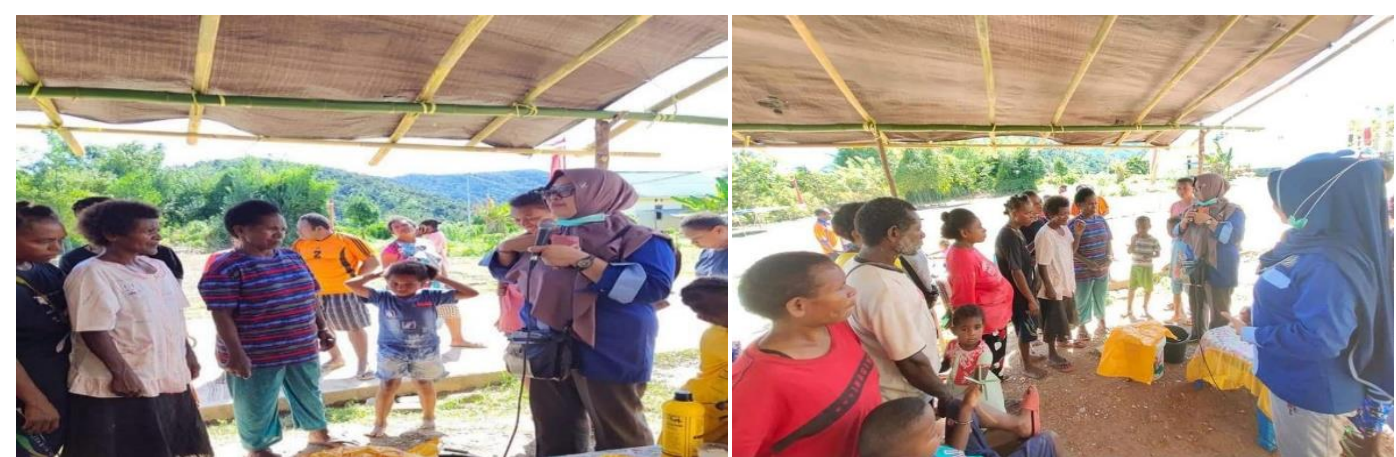

Gambar 1. Sosialisasi kepada masyarakat kampung Nanggouw

Disamping memaksimalkan pengenalan tumbuhan berkhasiat obat yang berasal dari hutan alam sekitar kampung Nanggouw, dalam penyuluhan ini dikenalkan pula beberapa jenis tanaman yang secara umum di ketahui berkhasiat obat sebagai berikut:

Tabel 1. Contoh tanaman obat keluarga

\begin{tabular}{lll}
\hline No & Nama Tanaman & Manfaat \\
\hline 1 & Seledri (Apium graveolens) & Mengobati tekanan darah tinggi \\
2 & Miana (Coleus artopurpureus) & Mengobati wasir \\
3 & Kemuning (Murraya paniculata) & Mengobati penyakit gonorrhoea \\
4 & Papaya (Carica papaya,L) & Mengobati demam dan disentri \\
5 & Kumis Kucing (Orthosiphon stamineus) & Memperlancar buang air kecil \\
6 & Sukun (Artocarpus comunis) & Menurunkan kolestrol dan asam urat \\
7 & Kelor (Moringa oleifera) & Mengatasi panas dalam dan demam \\
8 & Jambu biji (Psidium guajava) & Mencegah diare, ginjak, jantung, liver \\
9 & Salam(Eugenia polyantha) & Mencegah kangkerm kolestrol \\
10 & Kayu manis(Cinnamommum burmanii) & Mengobatu batuk dan sesak napas, nyeri \\
& & lambung, diare, rematik \\
11 & Jeruk nipis (Citrus aurantifolia) & Obat kumur antiseptik \\
12 & Pinang (Areca catechu) & Obat cacing \\
13 & Belimbing wuluh (Averhoa bilmimbi) & Mengobati batuk dan mengencerkan dahak \\
14 & Mengkudu (Morinda citroefolia) & Amandel, batuk, lever, sariawan \\
15 & Pala (Myristica) & Mengatasi kembung, saluran pencernaan, \\
16 & Kunyit (Curcuma domestica) & Sakit kepala, obat batuk,hepatitis \\
17 & Temulawak(Curcuma xanthorriza) & Asam urat, kolestrol, kadar gula darah, maag \\
18 & Lengkuas (Languas galangal) & Obat panu \\
19 & Alang-alang (Imperata cylindrica) & Memeprlancar air seni \\
20 & Kangkung (Ipomoea aquatic) & Mengobati insomnia \\
\hline & &
\end{tabular}
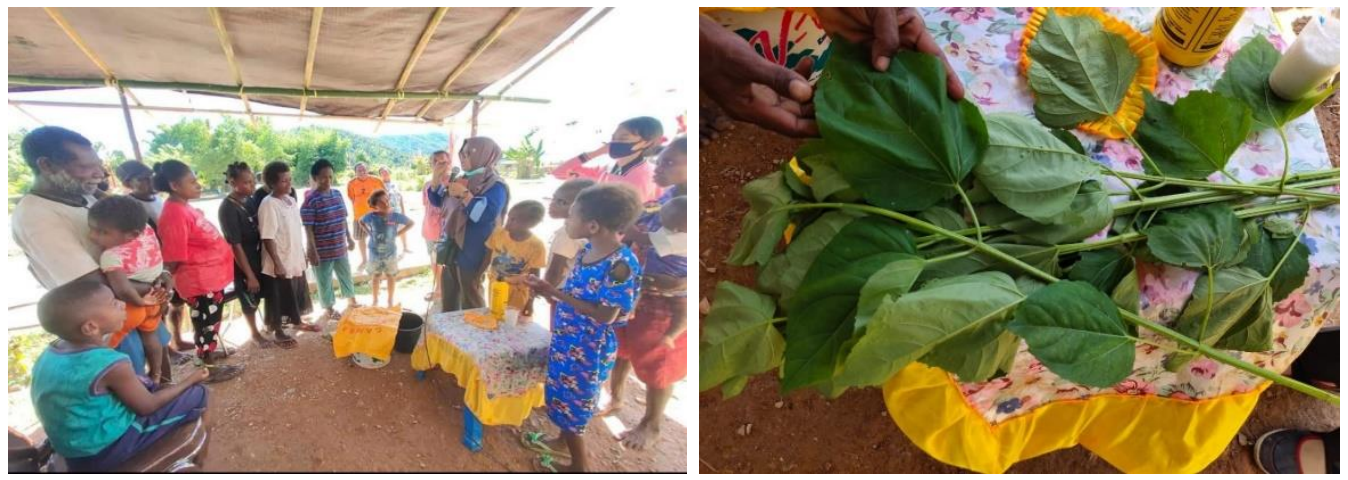

Gambar 2. Pengenalan langsung tumbuhan yang ada disekitar kampung kepada masyarakat Selama kegiatan sosialisasi, antusiasme masyarakat terhadap keingintahuannya mengeani 
jenis dan khasiat tanaman obat begitu tinggi. Hal ini dibuktikan dari interaksi masyarakat yang sangat aktif dalam bertanya kepada pemateri maupun langsung mencari tanaman yang berkhasiat sebagai tanaman obat yang ada disekitarnya. Tidak hanya wawasan atau pengetahuan tentang manfaat dari tanaman obat yang ditekankan pada kegiatan sosialisasi ini, tetapi juga lebih kepada dampak yang dirasakan oleh organ tubuh jika secara terus menerus mengkonsumsi obat-obatan kimia. Hal ini juga dikemukakan oleh Krisna (2020) bahwa setelah mengikuti kegiatan pelatihan, masyarakat lebih menyadari bahwa tanaman obat adalah salahsatu alternatif yang digunakan dalam kondisi seperti sekarang, yakni mampu meningkatkan system imun dalam memerangi covid-19. Selain itu, masyarakat juga menyadari bahwa kebanyak obat-obat kimia cenderung sangat mahal dan mengakibatkan dampak yang kurang baik pada organ tubuh manusia (Nugraha dan Agustiningsih, 2015; Bakti dkk, 2015).

\section{SIMPULAN}

Berdasarkan hasil kegiatan pengabdian yang telah dilaksanakan di kampung Nanggouw Distrik Sausapor dapat disimpulkan bahwa sambutan masyarakat dan aparat kampung sangat positif terhadap kegiatan yang dilakukan. Pengetahuan masyarakat terkait tanaman yang berkhasiat obat, pengolahan dan pemanfaatannya semakin meningkat sehingga kedepannya masyarakat kampung Nanggouw bisa lebih memaksimalkan tanaman obat sebagai alternatif pencegahan serta pengobatan berbagai penyakit secara alami.

\section{DAFTAR PUSTAKA}

Agusta, A. 2000. Minyak Atsiri Tumbuhan Tropika Indonesia. Penerbit ITB. Bandung.

Bakti, I., Dewi, E. A. S., Romli, R., dan Budiana, H. R. 2015. Analisis Faktor Personal pada Sumber Komunikasi dalam Pengelolaan Tanaman Obat Keluarga di Jawa Barat. Jurnal Kajian Komunikasi, 3(2), 7

Hikmat, A., Zuhud, E.A.M., Sandara, E., Sari, R.K. 2011. Revitalisasi konservasi tumbuhan obat keluarga (TOGA) guna meningkatkan kesehatan dan ekonomi keluarga mandiri di Desa Contoh Lingkar Luar Kampus IPB Darmaniaga Bogor. Jurnal Ilmu Pertanian Indonesia, 16 (2): 71-80.

Krisna, G. 2020. Sosialisasi Pemanfaatan TOGA untuk Ibu-Ibu PKK Desa Ringinputih Kabupaten Ponorogo. Jurnal Karinov, 3(2): 69-73.

Nugraha, S. P., dan Agustiningsih, W. R. 2015. Pelatihan Penanaman Tanaman Obat Keluarga (TOGA). 4(1), 5 .

Rahmawati, A.I.E., Hardiyanto, D., Azhari, F., dan Suminar, A. 2019. Sosialisasi, penyuluhan, penanaman, dan pemanfaatan tanaman obat keluarga (TOGA). Jurnal Pemberdayaan: Publikasi Hasil Pengabdian kepada Masyarakat, 3(3): 389-394.

Sari, S.M., Ennimay, dan Rasyid, T.A. 2019. Pemanfaatan Tanaman Obat Keluarga (Toga) pada Masyarakat. Dinamisia-Jurnal Pengabdian Kepada Masyarakat, 3: 1-7.

Savitri A. 2016. Tanaman Ajaib Basmi Penyakit dengan TOGA (Tanaman Obat Keluarga) Mengenali Ragam dan Khasiat TOGA Meramu Jamu Tradisional/ Herbal dengan TOGA. Bibit Publisher. Depok. 